\title{
The Organization of the Albanian Education System and the Status of the Italian Language in the Period 1920-1944
}

\author{
Albana Muceku \\ Albanological Research Centre, Tirana, Albania
}

\begin{abstract}
The article in question reflects in a summarized way the organization of the Albanian education system in the years 1920-1944, as well as the status and position of the Italian language in this system, during that period. The existing interest in the Italian language in Albania is closely related to the old relations the two countries have had. Notwithstanding fluctuations that such relations have undergone, this connection never disappeared. This long-standing relationship is the result of good neighborly ties built and maintained naturally by the people of the two countries. The wish of Ahmet Zog (the king in power at the time) and his cabinet was to create a state based on Western European models. Therefore, there was wide cooperation, not just in the economic and diplomatic field, but also in other areas, particularly concerning relations with the Italian state which at that period was the main supporter of Albania, and also with other western countries. Western European models served to establish and strengthen the Albanian state which had just been taking shape trying to follow the model European-leaning states. Based on historical facts, during the period 1920-1944, the Albanian educational system underwent numerous changes. These changes enabled the Albanian education system to take the form of a more unified and more developed model. The influence of the Italians in Albania was obvious in different fields such as the commercial, economic and social sectors. Given that this period was characterized by the intensification of the relations between Italy and Albania, it was inescapable that this relationship would be manifested also in the field of education. Therefore, this paper intends to demonstrate through historical facts extracted from press articles and publications of the time, the changes to the Albanian education system in the years 1920-1944, as well as the status of the Italian language during this period.
\end{abstract}

Keywords: Albanian education, Italian language, organization, influence, relations.

\section{Introduction}

Scientific works completed by Albanian authors (Koliqi H., 2002) indicated that after the formation of the first Albanian state, one of the main priorities of the first Albanian government was education. Until then education in Albania was characterized by:

Lack of a unique educational system.

A low number of schools.

Existence of many foreign schools.

Separate schools based on religious beliefs, which were supported by religious organizations of the three main religions existent in Albania.

A low level of education of the Albanian population, that was largely illiterate.

Changes that needed to be implemented in the Albanian education system were reflected in congresses organized in Lushnje which was held in 1920 and the second congress which was organized in Tirana in 1922. The Government of King Zog considered with priority the creation of a consolidated and uniform education system, similar to that of developed European countries. The support this government got from developed countries and mainly from Italy was immense. Changes made in the Albanian education system were reflected in the reshaping of the system of primary and secondary education and the creation of more vocational schools. Significant effort by the government at the time was 
devoted to the opening of foreign technical institutes, as well as grading of the teachers by their education level and professional training.

Given the fact that Italy was the main ally of Albania at the time, its impact in the Albanian education system was very big. Cooperation between countries and proliferation of Italian language and culture was on the rise, and it went as far as making the Italian language compulsory in high schools and vocational training schools.

\section{Stages of organization of the Albanian education system in the years 1920-1944}

The reformation of Albanian education system in the period 1920-1944 went through several stages. Among the most significant stages, which reflected further changes in this process, were the education Congresses held firstly in Lushnje and a second one in Tirana.

Beyond that, changes in the Albanian educational system continued with the application of decisions published in the official gazette, which determined the status of foreign languages, especially that of Italian language in the Albanian education system of that time. The influence of Italians made possible the introduction and dissemination of Italian language and culture in all educational levels.

\section{Education Congresses}

The first Albanian Education Congress was held in Lushnje in 1920 and was organized by the Ministry of Education. The main issues discussed in this congress were:

Establishment of a unified education system; the restructuring of schools; the organization and management of schools and other educational institutions; developing programs, curricula and textbooks at the national level; the unification of the Albanian language; the elevation of academic standards and training of teachers across the country; as well more issues of the didactic nature.

This Congress decided that elementary education consisting of five academic years, should be mandatory. Also, another first of this Congress was the categorization of teachers:

Category 1: Teachers who had completed the university (Abroad).

Category 2: Teachers who had completed "Normale" school or higher education.

Category 3: Teachers who had completed Turkish primary normal schooling by expedient classes or Greek urban schools with practice courses.

Category 4: Teachers who had completed Albanian or Turkish urban schools.

Special attention was devoted to the unification of educational records such as the registers, diaries, minutes of meetings, list of official duties. School programs that were used as models were those of Austria. After this Congress concluded its session, a series of educational laws were drafted, laws that served as the basis of education legislation in Albania, some of which are:

The Law on the central organization of the Ministry of Education

The Law on the basic organization of the Ministry of Education

The Law on compulsory school attendance

The Law on appointment and transfer of teachers

The Law on school fees, scholarships etc.

Elbasan "Normale" school reopened, as well as Korca "Licée", the only high schools in the country.

At that time there were 574 schools in Albania, of which 3 were secondary, 12 urban schools, 519 primary schools, 4 kindergartens, 36 schools of belonging to minorities. In the 1921-1922 school year 25,197 students attended academic studies, of which 5889 girls and 863 teachers worked in this system. It was at that time when preschool programs started initially in Streha Vorfnore (Poor Shelter) and Streha Foshnjore (Infant Shelter). On July 21, 1921 in Tirana, Albania a 
Technical School run by Harry Fultz opened; a vocational school, based on the American pragmatist concept. In the same year the "Illyrikum" Franciscan Gymnasium opened in Shkodra. This was a western-style school which regardless of the extensive support by the Franciscans, was in fact controlled and monitored by the state. A year later in 1922, in the city of Shkodra another gymnasium opened its doors the Public High School and the "Normale" high school run by Stigmatine Sisters. These were followed by other schools like the Boarding-School in Kosovo.

This great educational movement was accompanied by publication of many pedagogical journals such as "Teacher" (1922) The first pedagogical magazine the "New School" which was published earlier in Shkodra and later in Tirana and was run by Prof. Michael Gasper. "Pedagogical Magazine" (1922-1927).

\section{The second Albanian Education Congress (Tirana 1922)}

This Congress was held in Tirana on July 22, 1922. About 40 teachers participated in this congress. The decisions of this Congress were mainly related to:

The democratization of education and its modernization.

A new educational system was approved and stating that primary schools in the city would consist of 6 academic years and in villages 4 .

Establishment of vocational schools consisting of 3 academic years, to be attended by children who had completed the fifth grade.

High schools would be attended for 6 academic years.

\section{Abolition of urban schools.}

Many changes were approved in new programs mainly associated with primary schools which introduced subjects such as practical work, increased the number of science classes, reduced the number of hours of religion in order for schools to have a more secular approach, departing from their religious character. The new school system took effect in the academic year 1922-1923.

\section{The second Congress of Tirana (1924)}

The second Congress of Tirana was held on July 21, 1924. This Congress drafted and published the "Declaration of Albanian Teachers". Many important decisions were the attribute of this Congress such as:

Unification of the education system in all schools nationwide.

Strengthening the democratic foundations of the Albanian education system.

Increasing the number of new schools.

Compulsory education to become mandatory for boys and for girls.

Opening of kindergartens for children aged 5-7 years.

Opening of a girl's school to help educational and cultural status of women.

Opening partial high schools in Berat, Durres, and Elbasan.

This congress established The General League of Albanian Teachers.

\section{The structure of the Albanian education system}

Ahmet Zog's selection as head of the Albanian state was followed by numerous changes in the country. The intention of Ahmet Zogu and his cabinet was to create a modern state following the European model. For this reason, the cooperation not only in the economic and diplomatic fields, but also in other areas, particularly with Italian state, which at that period was the main supporter of Albania and also with other western countries, was very extensive. Western models served to establish and strengthen the Albanian state which had started to take its shape as a state with European affinities. So the new Criminal Code was drafted based on the Italian model, the new civil code that was modeled after the French and 
Swiss codes, the first Commercial code followed the Italian model, as did the organization and the structure of the army. Amid these efforts to build a modern system according to European models, education could not remain outside the focus of the state. In an interview given to "Corriere della Sera" Ahmet Zog stated that the first thing he intended to accomplish was the improvement of education and culture throughout the country, because the country's future depended on the advancement of these fields. During the years 1925-1926 were published the school programs for elementary schools consisting of six academic years, as well as the programs of male and female "normale" (equivalent of high schooling) school. According to the program near any "normale" school a training school was to be available so that the students of these schools would have the opportunity to perform their practical academic training. In the following years educational reforms followed one another.

Hence elementary schools from 6 academic years were diminished to 5 (during1928-1940), many new schools opened e.g. the Albanian-American Agricultural School Kavaja, as well as many other professional schools. Despite the influence and the opening many foreign schools, the government's primary goals were the education and upbringing of young Albanians with love for their homeland and allegiance to their state and Albanian institutions. For this reason, in 1933 the Albanian Parliament issued a law for the nationalization of all foreign schools (decree law approved of Prime Minister's Office, dated 10.09.1934).

In the years 1934-1935 the educational system in Albania had the following structure:

Kindergarten

Elementary school

Secondary schools (which had different branches)

Gymnasium

Normale

Vocational schools

The new law on the Albanian education system, adopted in the following years, provided that primary schools should consist of 5 academic years, gymnasiums of 8 academic years, urban schools of 4 academic years, "Normale" schools 4 academic years which were to follow the 4 years of high school. Primary education had a mixed organizational system, while the secondary education was separate for boys and for girls. The exception to this was the National Korca Lycée, "Normale" of Elbasan and the Urban School of Berat. High schools of that time according to the "Law on high school reform" of 1938 were classified as follows:

Vocational Schools

Technical Institute

"Normale" schools

Lycée

All these schools consisted of two levels (degrees):

Low levels, which included vocational schools, low courses of the technical institute, low courses of "Normale" school, low courses of Lycée.

High levels, which included the high courses of technical Institute, high courses of "Normale" school and high courses of Lycée.

This period (1938-1939) was characterized by a significant increase in the number of students at all school levels and in the number of new schools, an increase in the number of professionally trained teachers who completed their training courses or graduated schools abroad. 
Albania had:

23 kindergartens, where 2434 children were enrolled,

643 primary schools attended by 52,024 students,

22 secondary schools,

1660 teachers,

380 education specialists who had completed their education abroad.

Furthermore, the number of students who choose to continue their education abroad increased significantly, mainly in countries like Italy, Greece, Germany, Austria, and these numbers kept growing with the arrival in power of Ahmet Zogu. A significant number of these scholarships were awarded by the General Directorate of Italian schools abroad in cooperation with their representative offices in Albania (Archival documents1924, Archival documents 1925). This great educational movement was accompanied by the publication of journals and periodicals derived from various Albanian specialists who intended to boost the quality of teaching through texts or translations published in different languages in various developed European countries. "Pedagogical Magazine" (1922-1927); "The Teacher" (1927-1929); "National School" (1937-1939); "Normalisti" (1929-1937). Albanian teachers offered a great contribution to this process, in cooperation with foreign specialists who jointly tried to bring a new spirit of a progressiveness and democracy to the Albanian education. Here we might mention the pedagogical publications by Gasper Belortaja; "Theoretical Pedagogy for elementary school teachers," by Alexander Xhuvani, with the second publication of this volume. After the fascist occupation education, as every other sector in Albanian society, underwent many changes. The intensification of relations between the two countries was slowly replaced by the implementation of complete control of the Italian government and Italianization of each sector. At the time of occupation, Italians found in Albania 660 primary schools (6-11 years), 19 second-level schools (11-13 years), 1595 teachers and 62,971 students. At this time in addition to existing high schools which were:

At this time in addition to existing high schools which were:

Gymnasiums (Lycée) in Shkodra, Tirana and Korca

"Luigj Gurakuqi" Normale School in Elbasan

"Nana Mbretneshë" all Female Institute

"Karl Gega" Technical Institute in Tirana

There were also three other vocational schools for boys in Kavaja, Berat, and Elbasan. Furthermore, 5 schools of agricultural profile and many two-year vocational schools were functional in different cities and towns of Albania.

\section{Status of foreign languages in the Albanian education system}

Referring to the facts mentioned above, which show the great efforts by the Albanians to build a unified and democratic education system based on the most developed European models of the time, a very important and special place was dedicated to the learning of the languages and culture of the developed European countries. Because Albania was a country lacking educated people and with a high number of illiterates, an educational system that at the was sporadic and relying primarily on education offered by religious organizations and individuals, the need of learning a foreign language that was a necessity at that time. The intensification of relations with Italy, France, Austria, and America somehow dictated the need for recognition of foreign languages. The government at the time gave priority to foreign language teaching mainly Italian language, which had the highest number of schools and students taught in them. This was due to the fact that Italy was the main partner of Albania in many sectors. So in a way, Italian language became the number one foreign language taught in all schools in the Albanian education system, with the exception of the primary schools where the Albanian government, by a special order, did not allow the teaching of any foreign language but only the native Albanian language. Linguistic policies followed by the government of King Zog demonstrated an excellent balance between Italian language and other foreign languages, French, English as well as German. Proof of this is the opening of such schools such as French Lycée, Harry Fultz Technical School in Tirana or the Albanian-American Agricultural School 
in Kavaja, where the French language and English were the primary foreign languages. It should be pointed out that despite the need to learn foreign languages Albanian was the primary language in all school levels. Especially at the elementary level a special government decision prohibited the teaching of a foreign language (Archival documents 1930).

This fact is confirmed by the law no. 52, published in the Official Gazette of 1933 , on foreign language teaching in high schools.

Article 1

"In all high schools, commercial and technical schools of the Kingdom the following languages will be taught: Italian, French, English, and German."

Article 2

"Of the above mentioned foreign languages in Article 1, the teaching of Italian language is mandatory for all students of the above mentioned schools, and starts from the first grade. Students in high schools, students of commercial schools, starting from the third grade are required to learn, in addition to the Italian language, one of the other foreign languages mentioned in the article above."

\section{Article 3}

"This Regulation shall enter into force in the academic year 1933-1934" (Archival documents 1933). Given this decision, the Italian language became the number one foreign language studied by Albanian students. For example, in the Industrial School of Applied Arts in Shkoder, the Italian language was taught every day of the week, from Monday to Saturday (Archival documents 1931). Italian language was mainly taught by Italian teachers and only in cases when there was a shortage of teaching staff, an Albanian teacher was permitted to replace them on the condition that he had completed his studies in Italy (Archival documents 1931). Following the government's decision to introduce Italian as a first language, all students had to take mid-term maturity exams and regular maturity exams of Italian and as French was not taught in the first year but in third it an exam was not required (Archival documents 1938). After the fascist occupation in 1939, the Italian language becomes mandatory and first language in all school levels. So students began studying other subjects in Italian language as well. During this period the study of Latin as a mandatory subject was introduced in high schools, but its hours were less intensive compared to the study of Italian, and also Greek language was introduced as part of the curriculum. Italian language was a mandatory exam subject at the end of school's years and graduation. This decision was applicable to all schools without exception (Archival documents 1940). The Fascist government tried to introduce the study of Italian language from the first grade of primary schools (Archival documents 1940). During the period 1940-1941 many Italian teachers came to Albania and were allocated mainly in high schools in Elbasan, Gjirokaster, Korce, Shkoder, Tirana Licée, "Nana Mbretneshë" Female Institute, Vlore, etc. (Archival documents 1940).

Hence, Albanian students besides the language also absorbed the Italian culture. In many high schools, especially those in the second tier, the Education Ministry had introduced a subject called General Culture. Below are examples of questions for a preparation course titled General Culture (Archival documents 1931). Mainly, the subject of General Culture introduced knowledge relating to the basic notions of Italian grammar, geography, history, zoology, literature. Besides the introduction at all levels of high school, the Italian language was also taught in courses that took place in the evening. These classes were called evening courses (Corsi serali). They were held at the high school premises. Anyone who was willing to study and learn Italian could enroll in these courses. In some cases, the largest number of people, who wanted to enroll in such classes, was workers who needed knowledge of Italian in order to communicate with the Italian staff at the enterprise where they worked. Also in a significant number were children, and students who wanted to upgrade their knowledge of Italian. Groups were divided by age and the language level of people (Archival documents 1931). Italian language skills, which students learned, varied depending on the school profile and school ratings. For example, in Shkoder Industrial School in crafting classes during the first year, students were mainly taught dictation and reading in order to improve their reading and writing, grammar, to learn concepts and develop basic conversations skills keeping them simple and short. Also, the sectorial language elements were present. During the second year, work was focused in further developing language skills, but the themes were more diverse and the amount of knowledge greater (Archival documents 1931).

\section{Conclusions}


Reorganization of the Albanian education system was the result of:

Lack of a unified system of education.

Low number of schools.

Presence of many foreign schools.

Schools divided on the basis of religious convictions, which were supported by religious organizations of the three main religions in Albania.

A low level of education of the Albanian population, which for the most part was illiterate.

2. Western Schools were the model to follow in order to make reform of the entire educational system in Albania possible.

3. Necessary changes were observed not only in the reorganization of classes and schools, but also in the classification of teachers, who were categorized based on their level of education and the school that they had attended.

4. Special attention was given to the drafting of programs, plans and textbooks at national level, the unification of the Albanian language, the establishment and training of teachers across the country as well as to issues of a more didactic character.

5. Given the strong ties with Italy and the priorities of the Albanian government at the time, in relation to numerous agreements with Italy in many vital sectors for the country, it is obvious that the dominance of Italy in the educational sector was evident. The decision to make Italian a compulsory language to be studied in high schools, led to a greater dissemination of Italian culture not only in schools but also in the social and cultural life of the country.

\section{References:}

[1] Archival documents (1924): Elenco borsisti della circoscrizione consolare di Scutari, Valona. Fund of saved records no. 163, file 196, page 3, 4. Central State Archive in Tirana, Albania.

[2] Archival documents (1925): Elenco borsisti della circoscrizione consolare di Albanese. Fund of saved records no. 163, file 251, page 7, 8. Central State Archive in Tirana, Albania.

[3] Archival documents (1930): The government's decision to close the foreign language in the primary school system. Fund of saved records no. 195, file 72, 81, page 9,66, 78. Central State Archive in Tirana, Albania.

[4] Archival documents (1931): Fund of saved records no. 176, file 176, page 76. Central State Archive in Tirana, Albania.

[5] Archival documents (1931): Fund of saved records no. 195, file 176, page 252. Central State Archive in Tirana, Albania.

[6] Archival documents (1931): Fund of saved records no. 195, file 176, page 183. Central State Archive in Tirana, Albania.

[7] Archival documents (1931): Scuola Industriale di Coriza. Fund of saved records no. 195, file 176, page 330. Central State Archive in Tirana, Albania.

[8] Archival documents (1933): The official journal no. 52. Central State Archive in Tirana, Albania.

[9] Archival documents (1938): Fund of saved records no. 195, file 95, page 12. Central State Archive in Tirana, Albania.

[10] Archival documents (1940): Records and summary statements of exams. Fund of saved records no. 195, file 613. Central State Archive in Tirana, Albania.

[11] Archival documents (1940): Records and summary statements of exams. Fund of saved records no. 195, file 553 and 754, page 3, 5-12. Central State Archive in Tirana, Albania.

[12] Koliqi H., (2002): History of education and pedagogical thought. Publishing House, Prishtina, Kosova. pp. 347435. ISBN 9951-07-084-1. 